\title{
Spatiotemporal Variation Characteristics of Groundwater Quality in A Semi-Arid Steppe Area in Northwest China
}

\author{
Quansheng Li*, Kai Zhang*, Yingming Yang*, Shan Chong**, Wenfeng Du** and Yunlan He**† \\ * National energy group, State Key Laboratory of water resources protection and utilization in coal mining, Beijing \\ 100011, China \\ ** State Key Laboratory of Coal Resources and Safe Mining, China University of Mining and Technology (Beijing), \\ Beijing 100083, China \\ $†$ Corresponding author: Yunlan He; yunlanhe@pku.edu.cn
}

Nat. Env. \& Poll. Tech.

Website: www.neptjournal.com

Received: 01-02-2021

Revised: 26-03-2021

Accepted: 13-04-2021

Key Words:

Semi-arid steppe

Spatiotemporal variation

Groundwater quality

Northwest China

\begin{abstract}
In this paper, the open-pit coal mine in semi-arid grassland was taken as the research object. The water samples of the open-pit coal mine and its surrounding areas were collected and the hydrochemical parameters were detected. The temporal and spatial distribution characteristics of the parameters such as $\mathrm{pH}$, electrical conductivity, and dissolved oxygen in the groundwater were studied. The results showed that the groundwater in the study area was alkaline and brackish water. Climate factors might have a certain impact on the $\mathrm{pH}$, conductivity, and dissolved oxygen of groundwater. The $\mathrm{pH}$ value of groundwater in the mining area was higher than that in the surrounding pastoral area, while the conductivity value of the mining area was between the pastoral area in the west and the Xilin river area in the east. The parameters of $\mathrm{pH}$, conductivity and total dissolved solids of the four monitoring wells around the mining area showed a slow change or stable phenomenon in the vertical direction with the increase of groundwater depth. This study is of great significance to understand the characteristics of groundwater chemistry in mining areas and the rational development and utilization of groundwater resources.
\end{abstract}

\section{INTRODUCTION}

Groundwater is an important natural resource in human production and life, and also a decisive factor to maintain the balance of the ecological environment, especially in the arid and semi-arid grassland areas. Human activities, such as coal mining, will disturb the groundwater in the grassland area (Liu et al. 2017), and the groundwater level and some water quality parameters may change dynamically with time and space. Therefore, it is of great significance for the protection of groundwater resources and ecological restoration to investigate the dynamic characteristics of groundwater in an arid and semi-arid grassland.

At present, the research on the characteristics of groundwater dynamic change is one of the hot spots of scholars at home and abroad (Jia et al. 2018). By studying the changing law of groundwater dynamic factors, we can not only understand the changing trend of each factor but also take appropriate measures to deal with the possible environmental problems as soon as possible. The temporal and spatial distribution characteristics of groundwater level and hydrochemistry are affected by both natural and human factors, including precipitation, evaporation, terrain structure, and human exploitation (Jain \& Vaid 2018, Barzegar et al. 2018, Thakur et al. 2018). Among them, the research on the spatial distribution characteristics of groundwater quality has direct significance for the identification of groundwater pollution source and degree (Hao et al. 2018, Rasool et al. 2018, Zhang et al. 2017, Oufline et al. 2012). The study on the dynamic change of groundwater can explore the impact of mining activities on groundwater, predict the inflow of mine pit water, and ensure the safety of mining activities (Wu et al. 2019). At the same time, as an important resource, the change of groundwater is of great significance to social development and ecological protection (Sun et al. 2021, Jiang et al. 2020, Zhou et al. 2020). Therefore, it is very important to study the dynamic characteristics of groundwater for the rational development and utilization of groundwater resources.

The current research shows that the original balance state and circulation relationship of groundwater were affected in the process of opencast coal mining due to the discharge of mine water, the drainage of aquifer, the leaching of the waste dump, and the damage of mining, which was manifested by the drop of groundwater level in different degrees and the change of water quality parameters (Oufline et al. 2012). There are many studies on the groundwater quality 
in open-pit coal mine areas, such as the evaluation of water quality in coal mining (Lin et al. 2016) and the migration characteristics of groundwater quality along the pollution source (Huang et al. 2016). Although the spatial distribution characteristics of groundwater quality parameters and the analysis of water quality differences are important contents of groundwater research (Kurdi \& Eslamkish 2017, Kumari et al. 2014, Arslan \& Turan 2014), there are few related studies carrying out in domestic open-pit coal mine areas.

In this paper, we take the open-pit coal mine in a semi-arid grassland area as the research area to study the temporal and spatial variation characteristics of groundwater quality in the mining area and surrounding areas during the development of open-pit coal mines. The spatial differences of groundwater quality parameters distribution were analyzed and the influence of open-pit coal mining on groundwater quality parameters was discussed. This study is of great significance to understand the characteristics of groundwater quality and the rational development and utilization of groundwater resources.

\section{Study Area}

The open-pit mining area is located in the middle of Xilingol grassland, which belongs to a part of the hydrogeological unit of the Xilinhot basin. The ground elevation is 980-109 $3 \mathrm{~m}$, and the terrain is high in the northwest and low in the southeast. This area belongs to a semi-arid grassland climate, cold in winter and hot in summer, with a large annual temperature difference. The extreme maximum temperature is $38.3^{\circ} \mathrm{C}$, and the minimum temperature is $-42.4^{\circ} \mathrm{C}$. The annual average precipitation was $293.45 \mathrm{~mm}$, and the annual average evaporation was $1794.64 \mathrm{~mm}$.

There are faults F1 and F25 in the early mining area of the mine (Jiang et al. 2013), all of which are normal faults with strike NE and dip angle greater than $50^{\circ}$. The open-pit mine is located in the hanging wall of the fault. The fault forms the water separation boundary, and the east, north, and west are the supply boundary.

\section{MATERIALS AND METHODS}

Through sorting out and analyzing various data of the openpit mine, 16 representative groundwater monitoring points were selected according to the hydrogeological conditions and characteristics of the mine area, as shown in Fig.1. HW1, HW2, HW3, HW4, HW5, HW6, HW7, and HW8 were monitoring points of hydrological wells, CW1, CW2, CW3, CW4, CW5, CW6, CW7, and CW8 were monitoring points of civil wells. The underground water sampling method was as follows: water was pumped to the surface by pumps in civil wells, and water was collected by samplers in hydrology wells at a depth of $1 \mathrm{~m}$. A $1.5 \mathrm{~L}$ sampler was used to sample the groundwater from the hydrological well. When the sampler contacted the groundwater-surface in the borehole, the rope was quickly released to the depth of $1 \mathrm{~m}$ below the water surface. After waiting for 3-5 min, the sampler was quickly pulled to the ground, and the water sample was quickly poured into the PTFE storage bottle. The indexes of $\mathrm{pH}$, electrical conductivity, and dissolved oxygen were detected by HACH MS5 portable water quality detector on site.

\section{RESULTS AND DISCUSSION}

\section{Temporal Variations of Groundwater Parameters}

$\mathrm{pH}$ is an indicator to measure the acidity and alkalinity of water. According to Fig. 2 (a), the distribution range of groundwater $\mathrm{pH}$ in the mining area and surrounding areas was between 7010 , but the $\mathrm{pH}$ of most groundwater varied

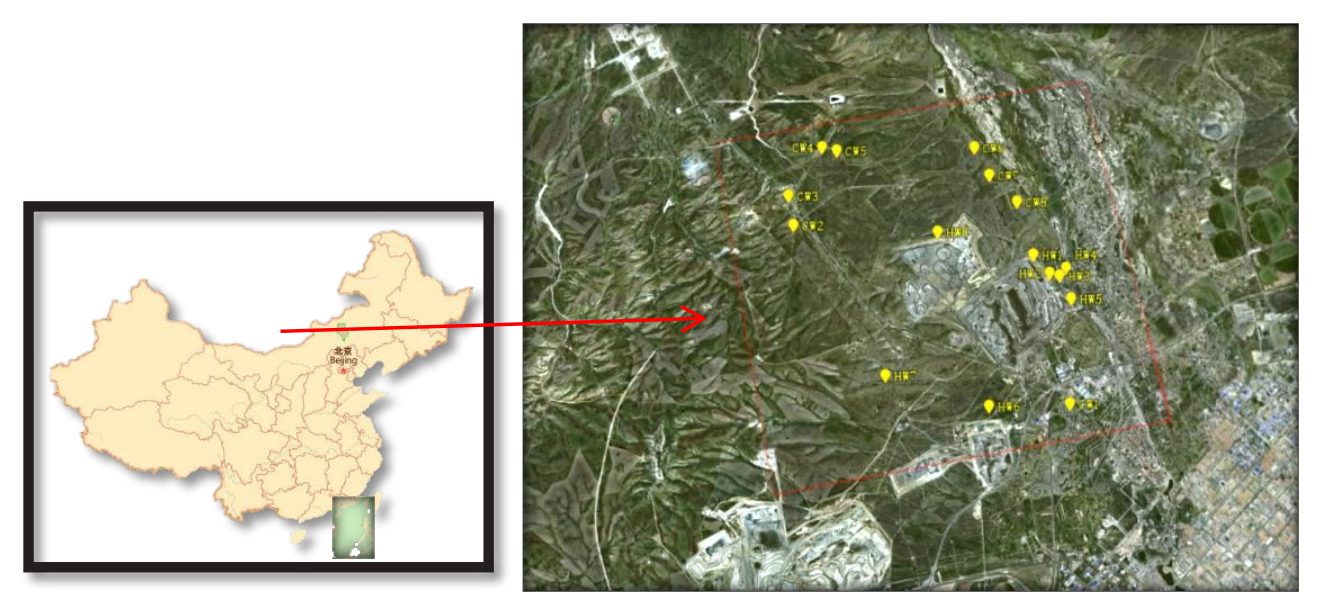

Fig.1: Map of geographic and sampling location. 

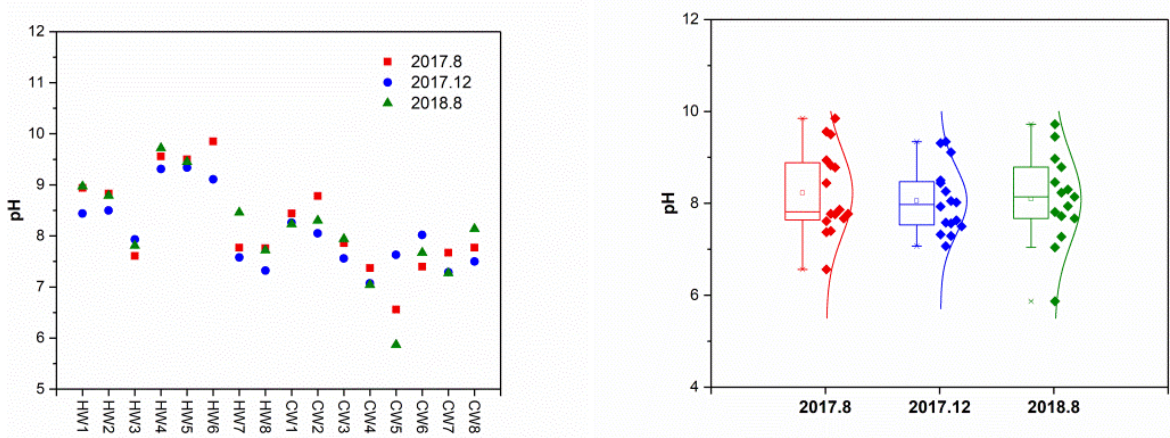

Fig. 2: Temporal variation of $\mathrm{pH}$ (a) each well (b) boxplot of all well.
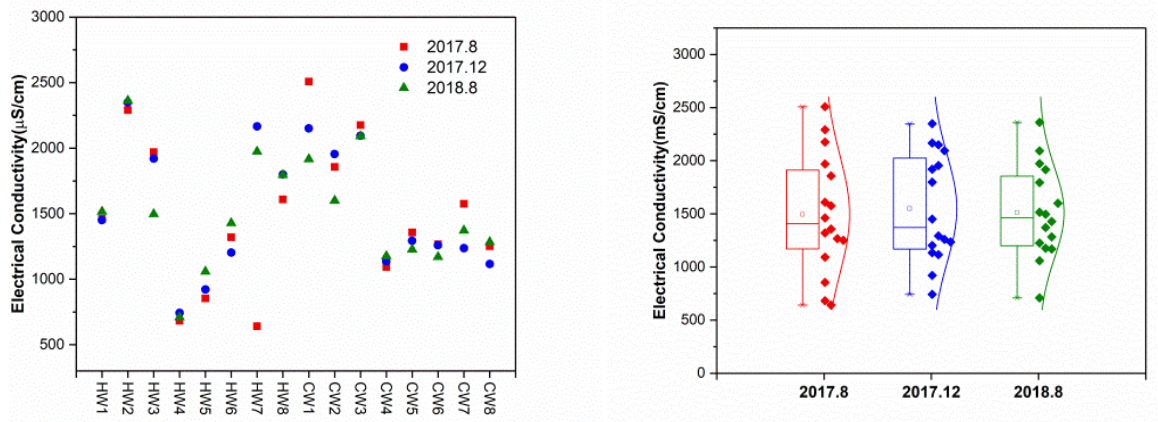

Fig. 3: Temporal variation of electrical conductivity (a) each well (b) Boxplot of all well.

between $7 \sim 9$, indicating that the groundwater in this area was neutral to slightly alkaline. In addition, the temporal variation of groundwater $\mathrm{pH}$ also showed the following uniform changes: the $\mathrm{pH}$ value of groundwater in winter 2017 was lower than that in summer 2017 and 2018; the $\mathrm{pH}$ value of groundwater in summer 2018 was higher than that in summer 2017. According to Fig.2 (b), it can be seen intuitively that the $\mathrm{pH}$ of most groundwater was between 7-9, among which three wells had a $\mathrm{pH}$ value higher than 9, which was reflected in the three sampling periods of August 2017, December 2017 and August 2018.

The electrical conductivity of water was often used indirectly to represent the total concentration of charged matter in water. The distribution of electrical conductivity in groundwater was influenced by comprehensive factors, such as formation lithology, geological structure, and groundwater circulation characteristics. According to Fig. 3 (a) and (b), the distribution range of groundwater electrical conductivity in the mining area and surrounding areas was $500 \sim 2500 \mu \mathrm{S} . \mathrm{cm}^{-1}$, and the electrical conductivity of most water samples was concentrated in the range of $1000 \sim 2200 \mu \mathrm{S} . \mathrm{cm}^{-1}$. The electrical conductivity of most groundwater samples in winter 2017 was lower than that in summer 2017, but some samples remained unchanged.
Through the boxplot, it can be seen intuitively that the average electrical conductivity of the groundwater samples first decreased and then increased during the three sampling periods of August 2017, December 2017, and August 2018.

Dissolved oxygen refers to the amount of oxygen dissolved in water, which is an indicator to measure the selfpurification capacity of water. As can be seen from Fig. 4 (a) and (b), the distribution range of dissolved oxygen in the mine area and surrounding groundwater was between $0 \sim 9$ $\mathrm{mg} . \mathrm{L}^{-1}$, and most of the dissolved oxygen in water samples was within the range of $2 \sim 9 \mathrm{mg} . \mathrm{L}^{-1}$. The dissolved oxygen value in winter 2017 was higher than that in summer 2017 and 2018, which was caused by the fact that the solubility of gas was related to the temperature of the liquid, and the solubility of oxygen in water decreased with the increase of water temperature. Silva et al. (2013) also found the same phenomenon when the dissolved oxygen in the surface and underground water of Lubango in Angola changed with seasons (Silva et al. 2013). Therefore, the low temperature in Xilingol in winter resulted in the increase of dissolved oxygen concentration in water, while the high temperature in summer resulted in the decrease of dissolved oxygen concentration in water. 

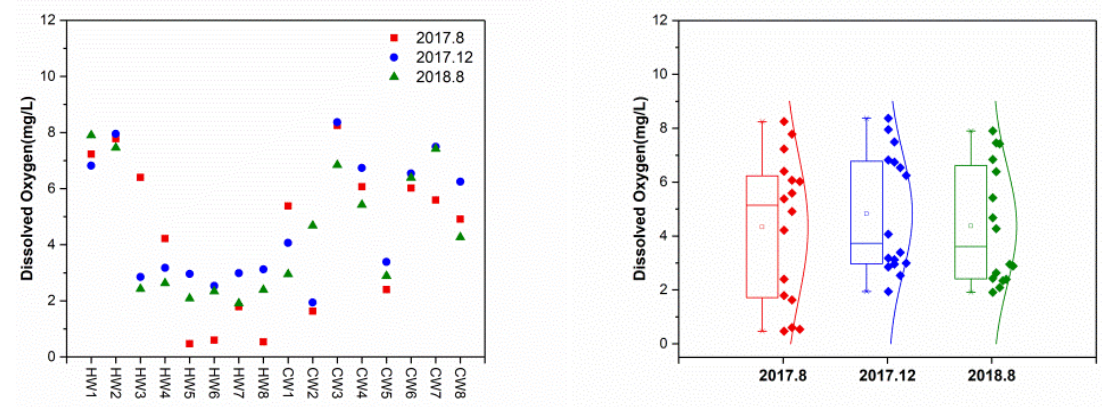

Fig. 4: Temporal variation of dissolved oxygen (a) each well (b) Boxplot of all well.

\section{Horizontal Spatial Distribution of Groundwater Parameters}

In this paper, the $\mathrm{pH}$, electric conductivity (EC), and dissolved oxygen (DO) of groundwater in the mining area and its surrounding areas were analyzed. These parameters were drawn by software surfer 8.5 and the Kriging interpolation method, and then the spatial distribution characteristics of physical and chemical parameters of groundwater were described.

As can be seen from Fig. 5, the pH of most water samples was between 7 9, and the $\mathrm{pH}$ of groundwater near the mining area was higher than that in the surrounding pastoral areas, among which the $\mathrm{pH}$ of groundwater in the western, northern pastoral areas, and the southern vegetable base was lower than 8.5. The $\mathrm{pH}$ value of groundwater near the pit and waste dump increased due to the drainage of coal mining. The highest $\mathrm{pH}$ value appeared at the HW3 hydrological monitoring point near the waste dump on the east side of the pit, where the groundwater was alkaline. In comparison to the $\mathrm{pH}$ value of groundwater in summer 2017, the $\mathrm{pH}$ range in the mining area and surrounding areas had significantly expanded in summer 2018. Therefore, it is inferred that mining activities may have a certain impact on the rise of groundwater $\mathrm{pH}$ in the mining area.

It can be seen from Fig. 6 that the electrical conductivity of most water samples was concentrated in the range of $1000 \sim 2200 \mu \mathrm{S} . \mathrm{cm}-1$. The distribution of electrical conductivity was characterized by high in the west and low in the east of the study area. The electrical conductivity value of groundwater in the west pasture was significantly higher than that in the east Xilin River area, while the mining area was in the middle zone. Due to the formation of groundwater funnel, formed by the drainage of open-pit mining, the sand gravel confined water, no.5 coal confined water, no. 6 coal confined water and quaternary phreatic water at the top of
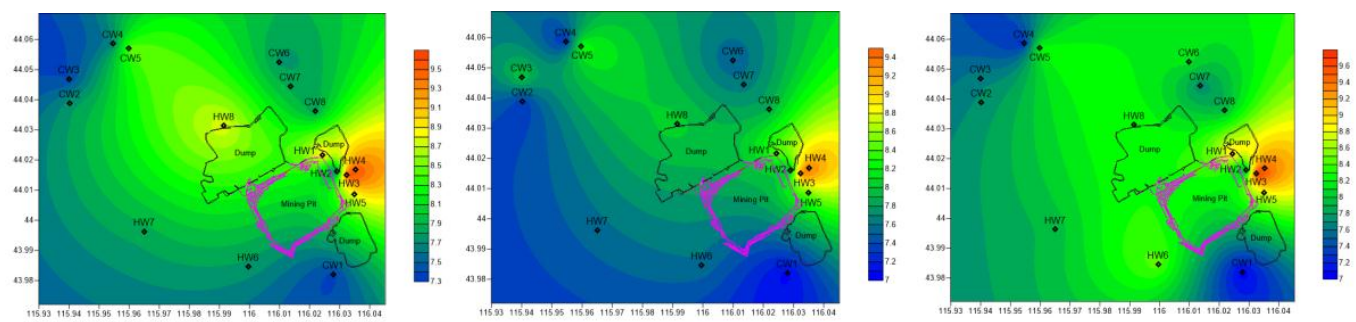

Fig. 5: Horizontal spatial distribution of pH (a) 2017.8 (b) 2017.12 (c) 2018.8 .
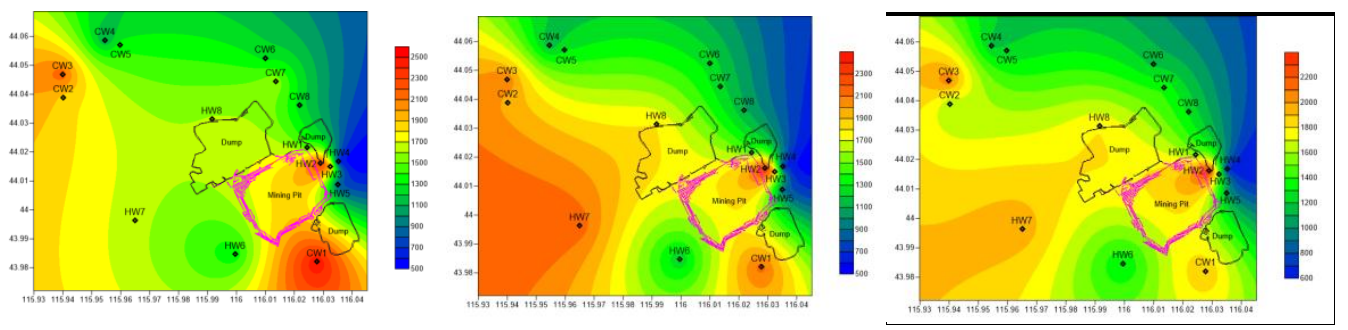

Fig. 6: Horizontal spatial distribution of electrical conductivity (a) 2017.8 (b) 2017.12 (c) 2018.8 

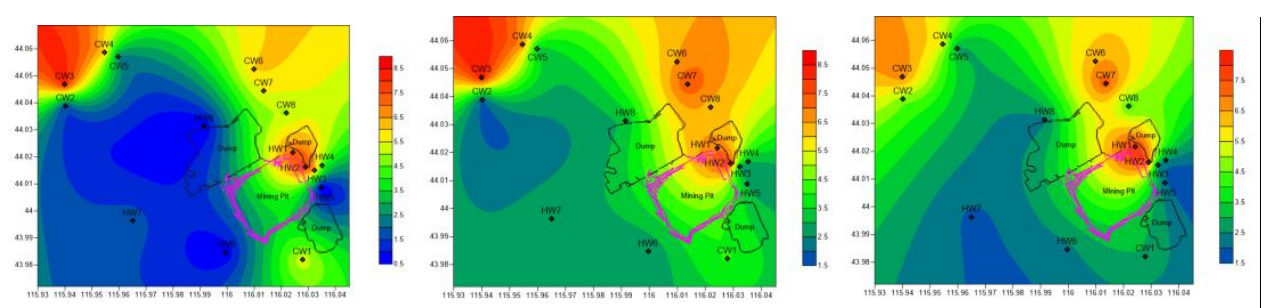

Fig. 7: Horizontal spatial distribution of dissolved oxygen (a) 2017.8 (b) 2017.12 (c) 2018.8

coal measure strata filled the mining pit. The high electrical conductivity groundwater in the west pastoral area and the low conductivity groundwater in the east river were mixed here, resulting in the conductivity value of the mining area between the two. In addition, compared with the summer of 2017 and the summer of 2018, the distribution range of high electrical conductivity in the western pastoral area in winter 2017 was relatively larger, which may be due to the strong evaporation of groundwater in the winter frozen period, while the precipitation recharge was less, resulting in a relatively high conductivity value of groundwater.

As can be seen from Fig. 7, the dissolved oxygen of most water samples was concentrated in the range of $2 \sim 9 \mathrm{mg} . \mathrm{L}^{-1}$. The content of dissolved oxygen had a great relationship with the sampling method. In the pastoral area, the main method of groundwater sampling was pumping. The groundwater was mixed with air drastically when it was pumped to the surface, which resulted in the high content of dissolved oxygen in the water samples. However, a sampler was used in the groundwater sampling of hydrologic well, and the sample extraction process had less contact with the air, so the dissolved oxygen content of groundwater samples obtained by this sampling method was relatively low. In addition, since the solubility of oxygen in water increased with the decrease of water temperature (Silva et al. 2013), the dissolved oxygen value of groundwater in winter 2017 was higher than that in summer 2017 and 2018, but the spatial distribution trend of these three periods showed the same characteristics.

\section{Vertical Spatial Distribution of Groundwater Parameters}

To further investigate the variation of groundwater chemical parameters with groundwater depth in the study area, we selected four monitoring wells (HW5, CW1, HW7, and HW8) distributed around the mining area, to study the vertical distribution characteristics of $\mathrm{pH}$, electrical conductivity, dissolved oxygen, total dissolved solids, and redox potential parameters. The sampling depth was designed according to the depth of the monitoring wells. Because the depth of the four monitoring wells was different, the sampling depth was also different. The sampling depth of well HW5 was 1, 5, $10 \mathrm{~m}$ below the water surface, well CW1 was 1, 5, 10, $15 \mathrm{~m}$ below the water surface, well HW7 was 1, 5, 10, 15, 20, 30, 40, $50 \mathrm{~m}$ below the water surface, and well HW8 was 1, 5, 10, $15,20,30,40 \mathrm{~m}$ below the water surface. The $\mathrm{pH}$, electrical conductivity, dissolved oxygen, total dissolved solids, and redox potential parameters of the groundwater samples were measured by a portable water quality detection instrument.

As shown in Fig.8, the pH of HW5, CW1, HW7, and HW8 had different trends with depth, and the pH of HW5 and CW1 showed an increasing trend with depth. The $\mathrm{pH}$ of HW5 increased from 8.79 to 9.37 with the groundwater depth increasing from $1 \mathrm{~m}$ to $5 \mathrm{~m}$, and then the $\mathrm{pH}$ remained basically stable within the depth range of $5 \sim 10 \mathrm{~m}$. The $\mathrm{pH}$ of CW1 increased from 7.04 to 7.42 with the groundwater depth increasing from $1 \mathrm{~m}$ to $5 \mathrm{~m}$, and the $\mathrm{pH}$ kept stable within the depth range of 5 15 m. With the increase of groundwater depth, the $\mathrm{pH}$ value of HW7 decreased first and then increased, and kept stable finally. The pH of HW7 kept stable at about 8.3 with the groundwater depth increasing from $1 \mathrm{~m}$ to $40 \mathrm{~m}$. With the increase of groundwater depth from $1 \mathrm{~m}$ to $10 \mathrm{~m}$, the $\mathrm{pH}$ value of $\mathrm{HW} 8$ decreased from 7.94 to 7.41 , and then the $\mathrm{pH}$ value increased from 7.41 to 7.77 with the depth increasing from $10 \mathrm{~m}$ to $20 \mathrm{~m}$, and finally kept stable within the range of $20 \sim 50 \mathrm{~m}$. The $\mathrm{pH}$ values and trends of the four wells were different, which may be related to the hydrogeological conditions of the location.

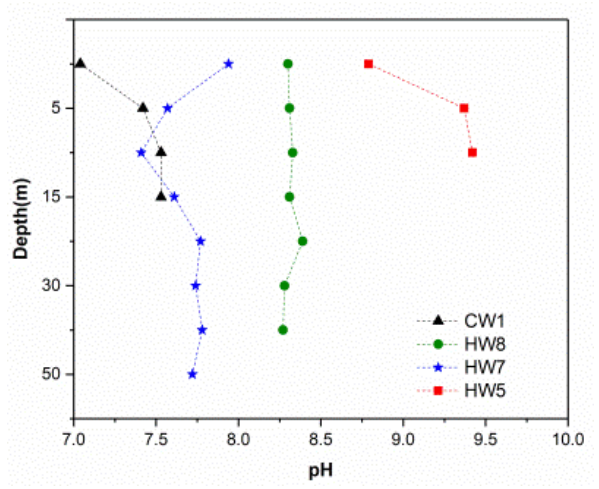

Fig. 8: Vertical spatial distribution of groundwater $\mathrm{pH}$ in groundwater. 


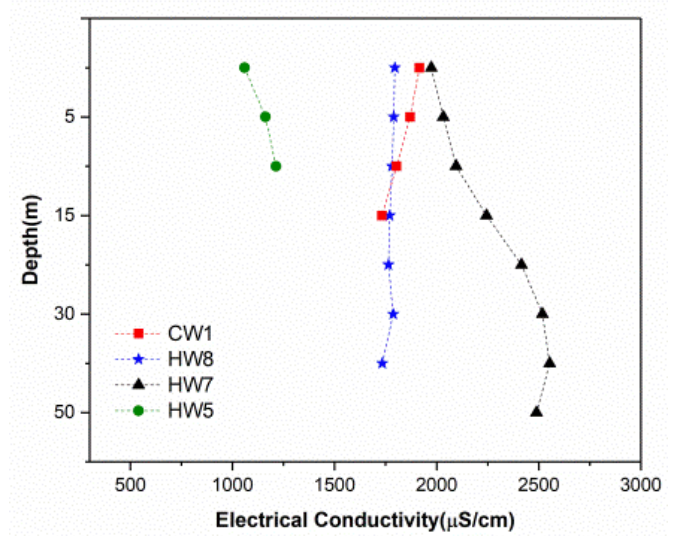

Fig. 9: Vertical spatial distribution of electrical conductivity in groundwater.

As shown in Fig. 9, the electrical conductivity values of four wells HW5, CW1, HW7, and HW8 also showed different variation trends with depth. The electrical conductivity of HW5 showed a slowly increasing trend and it increased from $1059 \mu \mathrm{S} . \mathrm{cm}^{-1}$ to $1213 \mu \mathrm{S} . \mathrm{cm}^{-1}$ with the depth of groundwater increasing from $1 \mathrm{~m}$ to $10 \mathrm{~m}$. The electrical conductivity of CW1 decreased from $1619 \mu$ S.cm ${ }^{-1}$ to $1732 \mu$ S.cm ${ }^{-1}$ with the depth of groundwater increasing from $1 \mathrm{~m}$ to $15 \mathrm{~m}$. As the groundwater depth of HW7 increased from $1 \mathrm{~m}$ to $50 \mathrm{~m}$, the electrical conductivity increased from $1974 \mu \mathrm{S} . \mathrm{cm}^{-1}$ to 2489 $\mu \mathrm{S} . \mathrm{cm}^{-1}$. As the groundwater depth of HW8 increased from $1 \mathrm{~m}$ to $40 \mathrm{~m}$, the electrical conductivity was basically stable at about $1790 \mu \mathrm{S} . \mathrm{cm}^{-1}$.

As shown in Fig.10, the changing trend of dissolved oxygen with groundwater depth in HW5, CW1, HW7, and HW8 was basically the same, both of which showed the trend of first increasing and then decreasing. As the groundwater depth of HW5 increased from $1 \mathrm{~m}$ to $10 \mathrm{~m}$, the dissolved oxygen increased rapidly from $2.09 \mathrm{mg} . \mathrm{L}^{-1}$ to $5.03 \mathrm{mg} . \mathrm{L}^{-1}$. As the groundwater depth of $\mathrm{CW} 1$ increased from $1 \mathrm{~m}$ to $15 \mathrm{~m}$, dissolved oxygen increased rapidly from $2.95 \mathrm{mg} . \mathrm{L}^{-1}$ to $4.81 \mathrm{mg} . \mathrm{L}^{-1}$ and then decreased to $4.18 \mathrm{mg} . \mathrm{L}^{-1}$, showing a phenomenon of increasing first and then decreasing, and an inflection point appeared at the depth of $10 \mathrm{~m}$. As the groundwater depth of HW7 increased from $1 \mathrm{~m}$ to $50 \mathrm{~m}$, the dissolved oxygen increased rapidly from $1.91 \mathrm{mg} . \mathrm{L}^{-1}$ to $3.88 \mathrm{mg} . \mathrm{L}^{-1}$, and then decreased slowly to $3.06 \mathrm{mg} . \mathrm{L}^{-1}$, with inflection points at $10 \mathrm{~m}$ and $40 \mathrm{~m}$, respectively. The variation trend of HW8 and HW7 was roughly the same, which increased rapidly from $2.39 \mathrm{mg} . \mathrm{L}^{-1}$ to $5.12 \mathrm{mg} . \mathrm{L}^{-1}$ and then decreased to $3.78 \mathrm{mg} . \mathrm{L}^{-1}$, but the inflection point appeared at $5 \mathrm{~m}$ and $20 \mathrm{~m}$, respectively.

As shown in Fig. 11, the changing trend of total dissolved solids with groundwater depth of HW5, CW1, HW7 and

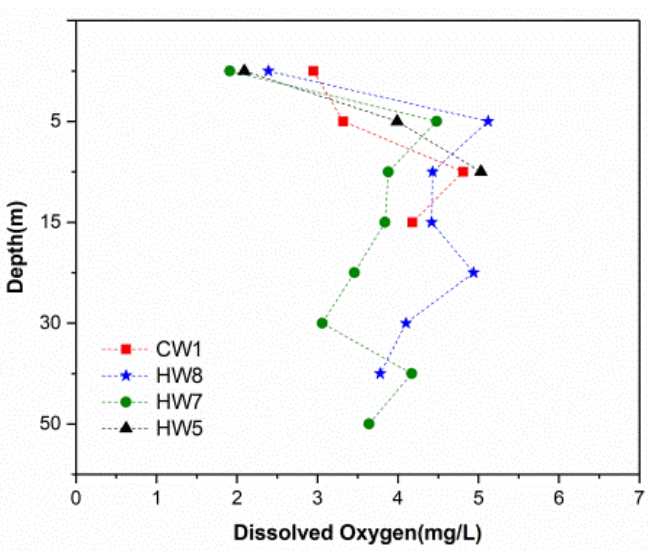

Fig. 10: Vertical spatial distribution of dissolved oxygen in groundwater.

HW8 was roughly the same as that of electrical conductivity. As the groundwater depth of HW5 increased from $1 \mathrm{~m}$ to $10 \mathrm{~m}$, the total dissolved solids increased from 528 mg. $\mathrm{L}^{-1}$ to $573 \mathrm{mg} . \mathrm{L}^{-1}$, showing a slow increase trend. With the groundwater depth of CW1 increasing from $1 \mathrm{~m}$ to 15 $\mathrm{m}$, the total dissolved solids decreased from $897 \mathrm{mg} . \mathrm{L}^{-1}$ to $832 \mathrm{mg} . \mathrm{L}^{-1} \mathrm{~L}$, showing a gradual decrease trend. With the groundwater depth of HW7 increasing from $1 \mathrm{~m}$ to $50 \mathrm{~m}$, the total dissolved solids increased from $933 \mathrm{mg} . \mathrm{L}^{-1}$ to 1126 mg. $\mathrm{L}^{-1}$. The total dissolved solids were basically stable at about $800 \mathrm{mg} . \mathrm{L}^{-1}$ with groundwater depth of HW8 increasing from $1 \mathrm{~m}$ to $40 \mathrm{~m}$.

\section{CONCLUSION}

In this paper, groundwater samples were collected from an open pit and its surrounding areas in a semi-arid grassland. The temporal and spatial distribution characteristics of $\mathrm{pH}$, conductivity, dissolved oxygen, and other parameters in

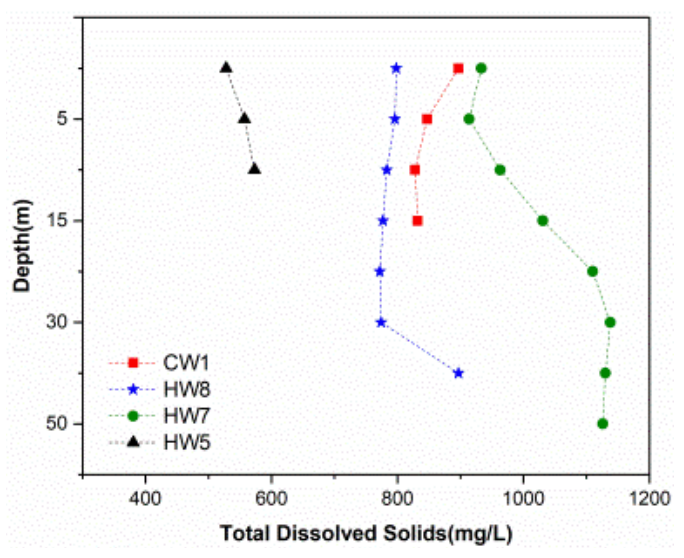

Fig. 11: Vertical spatial distribution of total dissolved solids in groundwater. 
groundwater were studied. The main conclusions of this paper are as follows:

1. The groundwater in the study area was alkaline and brackish water. Compared with summer, the $\mathrm{pH}$ and electrical conductivity of groundwater samples were relatively low in winter, while the dissolved oxygen was relatively high, indicating that climate factors might have a certain impact on the $\mathrm{pH}$, electrical conductivity, and dissolved oxygen of groundwater.

2. The $\mathrm{pH}$ of groundwater in the mining area was higher than that in the surrounding pastoral area, so it is inferred that mining activities may have a certain impact on the rise of groundwater $\mathrm{pH}$ in the mining area. The electrical conductivity of groundwater in the west pasture was significantly higher than that in the east Xilin river area. The drainage of coal mining would form an underground funnel near the mining pit, and the incoming water would be mixed near the mining pit, making the electrical conductivity value of the mining area between the two areas.

3. Four monitoring wells HW5, CW1, HW7, and HW8 around the mining area were selected to study the vertical distribution characteristics of $\mathrm{pH}$, conductivity, dissolved oxygen, total dissolved solids, and oxidation-reduction potential parameters. The increase of groundwater depth, $\mathrm{pH}$, conductivity, dissolved total solids, and redox potential showed a slow change or stable phenomenon, while dissolved oxygen changed dramatically. This trend may be related to the hydrogeological conditions of these wells.

\section{ACKNOWLEDGEMENTS}

The authors thank the support of the National Energy Group Key Laboratory Open Fund (GJNY 18-73.20), National Key Research and Development Program (2016YFC0501102), the Fundamental Research Funds for the Central Universities (2021YQMT01).

\section{REFERENCES}

Arslan, H. and Turan, N.A. 2014. Estimation of the spatial distribution of heavy metals in groundwater using interpolation methods and multivariate statistical techniques; its suitability for drinking and irrigation purposes in the Middle Black Sea Region of Turkey. Environ. Monit. Assess., 6(12): 187-199.

Barzegar, R., Moghaddam, A.A., Nazemi, A.H. and Adamowski, J. 2018. Evidence for the occurrence of hydrogeochemical processes in the groundwater of Khoy plain, northwestern Iran, using ionic ratios and geochemical modeling. Environ. Earth Sci., 77: 81-97.

Hao, A., Zhang, Y., Zhang, E., Li, Z., Yu, J., Wang, H., Yang, J. and Wang, Y. 2018. Review: Groundwater resources and related environmental issues in China. Hydrogeol. J., 26: 1325-1337.
Huang, X., Deng, H., Zheng, C. and Cao, G. 2016. Hydrogeochemical signatures and evolution of groundwater impacted by the Bayan Obo tailing pond in northwest China. Sci. Total Environ., 543: 357-372.

Jain, C.K. and Vaid, U. 2018. Assessment of groundwater quality for drinking and irrigation purposes using hydrochemical studies in Nalbari district of Assam. India, Environ. Earth Sci., 77: 111-141

Jia, Y., Xi, B., Jiang, Y., Guo, H., Yang, Y., Lian, X. and Han, S. 2018. Distribution, formation and human-induced evolution of geogenic contaminated groundwater in China: A review. Sci. Total Environ., 643: 967-993.

Jiang, D., Li, Z., Luo, Y. and Xia, Y. 2020. River damming and drought affect water cycle dynamics in an ephemeral river based on stable isotopes: The Dagu River of North China. Sci. Total Environ., 758: 143682.

Jiang, S., Kong, X., Ye, H. and Zhou, N. 2013. Groundwater dewatering optimization in the Shengli no. 1 open-pit coalmine, Inner Mongolia, China. Environ. Earth Sci., 69: 187-196.

Kumari, S., Singh, A.K., Verma, A.K. and Yaduvanshi, N.P.S. 2014. Assessment and spatial distribution of groundwater quality in industrial areas of Ghaziabad, India. Environ. Monit. Assess., 186: 501-514.

Kurdi, M. and Eslamkish, T. 2017. Hydro-geochemical classification and spatial distribution of groundwater to examine the suitability for irrigation purposes (Golestan Province, north of Iran). Paddy Water Environ., 15: 731-744.

Lin, M., Peng, W. and Gui, H. 2016. Hydrochemical characteristics and quality assessment of deep groundwater from the coal-bearing aquifer of the Linhuan coal-mining district, Northern Anhui Province, China. Environ. Monit. Assess., 188: 454-481.

Liu, P., Hoth, N., Drebenstedt, C., Sun, Y. and Xu, Z. 2017. Hydrogeochemical paths of multi-layer groundwater system in coal mining regions - Using multivariate statistics and geochemical modeling approaches. Sci. Total Environ., 601: 1-14.

Oufline, R., Hakkou, R., Hanich, L. and Boularbah, A. 2012. Impact of human activities on the physico-chemical quality of surface water and groundwater in the north of Marrakech (Morocco). Environ. Technol., 33: 2077-2088.

Rasool, A., Farooqi, A., Xiao, T., Ali, W., Noor, S., Abiola, O., Ali, S. and Nasim, W. 2018. A review of global outlook on fluoride contamination in groundwater with prominence on the Pakistan current situation. Environ. Geochem. Health, 40: 1265-1281.

Silva, M.M.V.G., Gomes, E.M.C., Isaias, M., Azevedo, J.M.M. and Zeferino, B. 2013. Spatial and seasonal variations of surface and groundwater quality in a fast-growing city: Lubango, Angola. Environ. Earth Sci., 76: 221-233

Sun, K., Hu, Li., Guo, J., Yang, Z., Zhai, Y. and Zhang, S. 2021. Enhancing the understanding of hydrological responses induced by ecological water replenishment using improved machine learning models: A case study in Yongding River. Science of the total environment,768: 145489 .

Thakur, D., Bartarya, S.K. and Nainwal, H.C. 2018. Tracing ionic sources and geochemical evolution of groundwater in the Intermountain Una basin in outer NW Himalaya, Himachal Pradesh, India. Environ. Earth Sci., 77: 549-571.

Wu, C., Wu, X., Zhu, G. and Qian, C. 2019. Predicting mine water inflow and groundwater levels for coal mining operations in the Pangpangta coalfield, China. Environ. Earth Sci.,130: 313-339.

Zhang, L., Qin, X., Tang, J., Liu, W. and Yang, H. 2017. Review of arsenic geochemical characteristics and their significance on arsenic pollution studies in karst groundwater, Southwest China. Appl. Geochem., 77:80-88.

Zhou, P., Wang, G. and Duan, R. 2020. Impacts of long-term climate change on the groundwater flow dynamics in a regional groundwater system: Case modeling study in Alashan, China. J. Hydrol., 590: 125557. 